\title{
KATILIM BANKALARINDA MUDAREBE FINANSMANINI ENGELLEYEN FAKTÖRLER
}

\section{HINDERING FACTORS OF MUDARABAH FINANCING IN ISLAMIC BANKS}

\author{
Muhammet Fatih CANBAZ* \\ Ahmet Sami ERDEN**
}

Öz

Katılım bankaları karlılık ve etkinlik açısından hızlı gelişimlerini sürdürürken uygulamaları ve alternatif finansman hizmetleri konusunda uzun zamandır aynı çizgide hareket etmektedirler. Bu durum uzmanlarca sürekli olarak eleştirilen bir politika haline gelmiştir. Katılım bankalarının murabaha gibi gelenekselleşen yöntemleri sürekli ve yüksek oranda kullanmasının sebepleri izah edilebilmektedir. Ancak mudarebe gibi yatırım ortaklığı kabiliyeti olan araçların neden kullanılamadığı hakkında net açıklamalara rastlanmamaktadır. Bu sebeple bu araştırmanın amacı katılım bankalarında mudarebe finansmanının önünde ne tip engellerin olduğunun tespit edilerek belirli faktörlere indirgenmesi olmuştur. Bu doğrultuda katılım bankalarında çalışan uzmanlardan alınan verilere uygulanan faktör analizinde altı engelleyici faktör belirlenmiştir. Bunlar; mudarebede ortaya çıkan yüksek riskle ilgili nedenler, girişimcilik ekosistemi ile ilgili nedenler, proje kârına bağlı nedenler, çalışanlara bağlı nedenler, mevzuata bağlı nedenler ve müteşebbislere duyulan güvene ilişkin nedenler olarak belirlenmiştir.

Anahtar Kelimeler: İslami Finans, İslami Bankacılık, Katılım Bankacılı̆̆ı, Mudarebe

JEL Sinıflandırması: G2, G24, B26

\begin{abstract}
Islamic banks have long been in the same line with their practices and alternative financing services, while maintaining rapid growth in profitability and efficiency. This policy constantly criticized by Islamic finance experts. Reasons why participation banks use certain financing methods, such as murabaha, are being explained. However, there is no clear explanation about why investment partner tools such as mudarabah are not available. Fort his reason, the purpose of this research was to identify and link to factors what types of obstacles are in front of mudarabah in Islamic banks. Six blockers were identified in the factor analysis applied to data from experts working at Islamic banks. These factors have been identified as reasons related to high risk in mudarabah, reasons related to entrepreneurship ecosystem, reasons related to project profit, reasons related to employees, reasons related to legislation and reasons related to trust in entrepreneurs.
\end{abstract}

Key Words: Islamic Finance, Islamic Banking, Mudarabah, Credit

JEL Kodu: G2, G24, B26

\footnotetext{
* Öğr. Gör. Dr.; Afyonkarahisar Sağlık Bilimleri Üniversitesi Sağlık Bilimleri Fakültesi, Sağlık Yönetimi Bölümü, canbaz@aku.edu.tr \& fatih.canbaz@afsu.edu.tr, ORCID: 0000-0002-4711-3489

** Yüksek Lisans Öğrencisi, İstanbul Üniversitesi, İslam İktisadı ve finansı yüksek lisans Programı, ahmeterden33@hotmail.com, ORCİD: 0000-0002-9120-5508
} 


\section{GİRiș}

İslami bankacılığa ilişkin çalışmalar incelendiğinde en sık karşılaşılan kavramların riskin paylaşımı, ortaklık kurma ve reel sektörün (üretim ve ticaret) desteklenmesi gibi ifadeler olduğu görülebilir. Bu başat ifadeler son 40 yılda literatürde birçok kez tekrarlanmış hatta İslami bankacıllığ Geleneksel bankacılıktan ayıran temel ifadelerden olmuşlardır. Bu kavramların kullanılmasında öne çıkan sebep ise İslami kaidelere göre hareket eden sektörden beklenen politika biçimleri olmalarıdır. İslam dini iktisadi muamelelerde ortaklık kurulmasını, garardan uzak durulmasını ve en önemlisi faizden beri şekilde riskin paylaşılmasını teşvik etmektedir. İslam'da risk paylaşımının en belirgin olduğu yöntemler düşünüldüğünde ise ilk akla gelen Mudarebe finansmanıdır.

Mudarebe (المضاربة) Arapçadan Türkçe'ye de geçen ve yol tepmek manasına gelen "eddarbu fil ardi" söylemindeki "darebe" kelimesinden türetilmiştir. Yol tepmekten kasıt ise ticaret için yola çıkarak elindeki malları satma eylemidir (Çeker, 2017). Ayrıca kelime Arapça "mufaale" kalıbından tanzim edilmiştir. Kelimenin zuhur biçimine de atıfla kavram olarak bir tarafin sermayesiyle (re'sül-mâl) diğer tarafin emeğiyle, ticari bilgi ve tecrübesiyle kurulan ticari bir ortaklık ilişkisini ifade etmektedir. Bu ortaklık sonucunda elde edilen kâr taraflar arasında maktu olmayan şekilde yani belirli oranlarda paylaşılmaktadır. Bu oranlar şözleşme yapıllıken belirlenmelidir. Eğer kar oranı şözleşmede belirlenmemiş ise kâr örfe göre o da yoksa yarı yarıya paylaşılmaktadır. $\mathrm{Bu}$ ortaklıklarda taraflara herhangi bir şekilde garanti kazanç vaad edilemez. Vaad edilmesi durumunda kar/zarar ortaklığı yapılmamış ve şirkete borç verilerek karşılığında faiz beklenilmiş demektir (Aktepe, 2017). Bu ortaklıkta sermayedara "rabbü'l-mâl" ve parayı işleten tarafa ise "mudarib" denilmektedir. Mudarib ortaklıkta girişimci rolüyle aktif bir biçimde yer alırken rabbü'l-mâl ise pasif ortak kabul edilmektedir. Bu ortaklık iki kişi arasında yapılabildiği gibi birden çok rabbü'l-mâl veya mudarib ile de yapılabilmektedir. Yöntem helâl kazancı emreden, rızık aramayı ve ticareti özendiren ayetler ${ }^{1}$, Hz. Peygamber'in bu yöndeki kavli ve takriri sünneti ${ }^{2}$, sahabenin uygulamaları vesilesiyle İslam'da meşru kabul edilerek geçmişten günümüze Müslüman toplumlar tarafindan yoğun biçimde tercih edilmiştir (Kallek, 2002). Yöntem ülke tecrübesi açısından Osmanlıda da yaygınca kullanılmış ve toplumda ciddi bir birikim meydana gelmiştir (Gedikli, 16. ve17. asır Osmanlı Şer'iyye Sicillerinde Mudarebe Ortaklığı : Galata Örneği, 1996). Ancak günümüz Türkiye'sinde riskin paylaşımını temel misyonları olarak ifade eden katılım bankalarında mudarebe finansmanının sunulmasında bazı sorunlar ve engeller olduğu görülmektedir.

Katılım bankalarının mudarebe yöntemini tamamıyla göz ardı ettiğini söylemek haksızlık olacaktır. Ancak yöntemin katılım bankalarında nasıl uygulandığı incelendiğinde tercih biçiminde katılım bankaları lehine bir pozitif ayrımın gözetildiği dikkat çekmektedir. Vakıa şu ki katılım bankaları mudarebeyi yüksek oranda fon toplama yöntemi olarak kullanmaktadırlar. Dolayısıyla müşterilerini sermayedar kendilerini ise emektar olarak konumlandırmaktadırlar. Yöntemin genel tercih biçimine bakıldığında bankalar yüksek oranda yatırımı veya işi kontrol eden emek tarafını temsil ederken müşteriler ise sermayeyi sağlayan taraf olmaktadır. Bunun tam tersi düşünüldüğünde yani herhangi bir müşteri yatırım yapacağını ifade ederek katılım bankalarından sermaye talep ederek ortaklık kurmak istediğinde genel teamülde katılım bankalarınca desteklenmedikleri görülmektedir. $\mathrm{Bu}$ politikanın önünde birçok mâkûl sebebin yattığı varsayılabilir ancak bu sebeplerin belirlenmesi bu politikanın değiştirilmesi adına önem arz etmektedir. Katılım bankalarınca gelenekselleşen bu davranışın yöntemin ruhunu tam yansıtmadığı noktasındaki eleştiriler uzun yıllardır müşteriler, İslam iktisadı uzmanları, yatırımcılar ve iş adamları tarafından sıkça dile getirilmektedir. Katılım bankalarının mudarebe yöntemiyle fon kullandırmasının sisteme yöneltilen eleştirilerin azaltılmasına ve sermaye problemi yaşayan yatırımcının desteklenmesine müspet katkılar yapmada önemli olduğu açıktır. Neticede bu destekleme davranışlarıyla geleneksel bankalarla aralarındaki farkları ortaya koyacak ve kuruluş amaçları olan riskin paylaşımına bilfiil katılacaklardır. Katılım bankalarında mudarebenin kullanımına ilişkin bu olumsuz durumun ortadan kaldırılması nedenlerin ortaya çıkarılması ile mümkündür. Bu çalışmada Katılım bankalarında mudarebe finansmanının yatırım yapmak isteyen müşteriler lehine uygulanmaması ya da uygulanamamasına ilişkin nedenler araştırılmış ve belirlenen nedenler tartışılmıştır.

\section{MUDAREBE ORTAKLIĞI}

Mudarebe yatırım yapma maksadıyla bir araya gelen iki kişinin birinin emeğini diğerinin ise sermayesini ortaya koyarak tesis ettikleri ortaklık anlaşmasıdır (Abidîn, 2005, s. 208). Belirli bir miktar paranın ticari faaliyetlerde kullanılarak kâr elde edilmesi halinde sermayedara önceden anlaşılan oranda kâr payı ve anapara geri ödemesi taahhüdüyle kurulan ortaklık türü (el-Mâverdî, 1989, s. 117) olarak da ifade edilmektedir. Mudarebe ortaklığında yatırımın fiilen emeğiyle yönetecek olan tarafa mudârib (işletmeci), sermaye sağlayan tarafa ise rabbu'l mâl (sermayedar) denilmektedir. Mudaribin ortaklıkta herhangi bir nakit sermayesi bulunmamaktadır.

\footnotetext{
1 (El-Müzzemmil 73/20; El-Cum‘a 62/10; El-Bakara 2/198)

2 (İbn Mâce, "Ticârât", 63; Ahmed B. Hüseyin El-Beyhakī, VI, 111)
} 
Mudaribin sermayesi entelektüel birikimi, tecrübesi ve zamanı olarak ifade edilirken bu emekleri karşılığında faaliyet sonucu oluşan kâra ortak olmaktadır.

Mudarabe risk paylaşımı içeren cari bir yatırım olması hasebiyle tarafların fayda elde etmeyi umarken zararla da karşılaşabileceği muhtemel akitlerdendir. Ticari faaliyet sonucunda kâr elde edilmesi halinde akitte anlaşılan oranlarda kâr taraflarca paylaşılırken zarar edilmesi halinde mali zarar tamamıyla sermayedara aittir. Normal şartlar altında icra edilecek olan bu zarar paylaşımı mudaribin zarar oluşmasında bir kastı olması halinde değişiklik arz edebilir. Yani mudaribin oluşan zararda herhangi bir kusuru ve kastı var ise mudaribden tazmin yoluna gidilebilir. Zarar paylaşımındaki temel usule bağlı olarak mudaribin zarara katılmadığı gibi bir görüntü ortaya çıksa da emek sahibi olarak katlandığı zarar zamanının ve çabalarının berheva olmasıdır. Bu faaliyetler esnasında sözleşmede özellikle kayıt altına alınmadı ise mudaribin herhangi bir şekilde maaş alma hakkının olmadığı da unutulmamalıdır. Dolayısıyla mudaribin kaybı olan zaman ve emeğin ticari hayatta ne denli önemli bir sermaye olduğu izahtan varestedir.

Mudarebe akdinin temelinde sermayesi olmasına karşın ticari bir faaliyet gerçekleştirme kabiliyeti veya zamanı bulamayan kişi ile kâr getirecek bir projeye sahip olduğu halde sermayesi olmayan kişinin bir araya gelerek her iki tarafın da menfaatlerine uyan bir iş anlaşması kurulması esası yatmaktadır (Serahsî, 2009, s. 19). Mudarebe anlaşmasıyla; ticari kabiliyeti bulunan girişimci sermaye ihtiyacını gidererek ticari hayata dahil olurken elinde nakit fazlası bulunan kişi ise ticari hayata katılma imkanına kavuşmaktadır. Her iki taraf içinde İslami finansın temellerinden olan risk paylaşımı esasına göre hareket edilmiş olmaktadır.

Mudarebede anlaşmalarında belirli kaideler özellikle zikredilmekte ve temel şartlardan kabul edilmektedir. Bu kaideler kısaca izah edilirse şu şekilde sıralanabilir.

- Mudarabe akdinde sermaye nakdî yani para cinsinden olmalıdır. Para dışında taşınabilir veya taşınamaz diğer mallar sermaye olarak kullanılamaz (Yaran, 2011, s. 583).

- Mudarib, şirketin yönetilmesinde sermayedarın koymuş olduğu şartlar dahilinde hareket etmelidir. Mudarib anlaşmada belirtilen şartlar ve ticari hayatın koyduğu sınırlar içerisinde özgür bir yönetim icra ederken sermayedâr ise işletme yönetimine müdahil olmamalıdır. Eğer mudaribce sözleşmede belirtilen şartlara riayet edilmiyor ise sermaye gasbedilmiş sayılmakta ve faaliyet sonucu oluşan tüm zararın tazmini gerekmektedir (Serahsî, 2009, s. 19).

- Mudarabe sözleşmesi yapılırken taraflar arasında kârın oransal olarak belirlenmesi gerekmektedir. Ĕ̆er kârdan alacakları pay açıkça belirtilmemiş veya kârdan belirli miktar para verileceği belirtilmiş ise sözleşme geçersiz (fâsid) kabul edilmektedir (Nevevî, 2006, s. 740). ${ }^{3}$

- Anlaşmada sermaye konusu varlık mudaribin elinde vedia (emanet) hükmündedir. Mutasarrıf olan mudarib ise sermayedârın vekilidir. Kasıt, kusur ve ihmal neticesinde zarar oluşursa mudarib bu zararı karşılamak zorundadir.

Mudarebenin meşru kabul edilmesi Kur'an-1 Kerim, Resûl-i Ekrem'in bu yöndeki kavlî, takrîrî sünneti ve sahabe uygulamaları ile sabittir (Durmuş, 2011).

Öncelikli kaynak Kur’an-1 Kerimde “yer yüzünde rızı aramayı ve ticareti teşvik” eden tüm ayeti kerimelerin genel anlamı mudarebeyi de meşru kılmaktadır. Sünnete bakıldığında ise tefsir ve fıkıh alanlarında itibar edilen ve çok sayıda hadis rivayet eden Hz. Muhammed'in (s.a.v) amcasının oğlu sahabe Abdullah İbn Abbas Hz. Muhammed'in mudarebeye ilişkin görüşünü şöyle ifade etmiştir: “Abbas, mudarebe yoluyla sermaye verdiğ $i$ zaman, ortă̆ına bu sermaye ile deniz yolculuğuna çıkmamasını, tehlikeli bir vadide konaklamamasını ve canlı hayvan ticareti yapmamasını şart koşardı. Ĕger bunları yapar ve zarar ederse anaparayı tazmin edecekti. Onun mudarebede öne sürdüğ̈̈ bu şartlar Hz. Peygamber'e ulaşmış ve o buna izin vermiştir." "Sahabe uygulamalarına bakıldığında ise Hulefâ-yi Râşidînden Hz. Ömer ve Hz. Osman'ın mudarebe ortaklığ yaptığı bilinmektedir. Yine sahabenin bu yöntemi uyguladığının kanıtı olarak şu anektod aktarılmaktadır. Hz. Ömer'in oğulları Ubeydullah ve Abdullah birlikte Irak’ta bir gazâya katılmışlardı. Dönüşte Basra Emîri Ebû Mûsâ el-Eş‘arî’yi ziyaret ettiklerinde Ebû Mûsâ halifeye göndereceği bir meblağı onlara teslim ederken bu para ile Irak’tan mal alıp Medine'de satmalarını, oraya varınca asıl parayı halifeye vermelerini, kazandıkları kârı ise kendilerinin almasını söyledi ve Hz. Ömer'e bunu açıklayan bir mektup yazdı. Ancak Hz. Ömer, halifenin oğulları oldukları için kendilerine devlet malıyla ticaret yapma imkânı tanındığını söyleyip ana parayla birlikte kârı da hazineye vermelerini onlara emretti. Oğulları risk üstlendiklerini ve karda hakları olduğunu savundular. Bunun üzerine

\footnotetext{
${ }^{3}$ Mecelle, Md. 1411.

${ }^{4}$ Zeylaî, Nasbu'r-Râye, IV, 114; Heysemî, Mecmau'z-Zevâid, IV, 161.
} 
mecliste bulunan sahabelerden biri bunun kâr paylaşımı ortaklığı (kırâz, mudârebe) sayılabileceğini belirtince Hz. Ömer bunu kabul ederek ana parayla birlikte kârın yarısını hazineye vermelerine razı olmuştur ${ }^{5}$.

\subsection{Mudarebenin Kısımları}

Emek/sermaye ortaklığı olarak kavramsallaşan mudârabe; sermaye sahibinin emek sahibine karşı işin yürütülmesi esnasında şart koşup koşmamasına göre mutlak veya mukayyet olarak 2 şekilde tesis edilmektedir.

a. Mutlak Mudârabe: Rabbü'l-mâlin herhangi bir şart veya kısıtlama belirtmeyerek mudaribi işin yürütülmesinde serbest bırakması halidir. Herhangi bir şart veya kısıtlama belirtmese dahi rabbü'l-mâl kâr paylaşımı hususunda paylaşma şekli ve ödeme zamanını belirleme hakkına sahiptir.

b. Mukayyet Mudârabe: Rabbü'l-mâlin işin yürütülmesinde mudaribden uymasını istediği birtakım şartlar veya kıstlamalar belirmesidir. Bu durumda mudarib belirlenen şartlara uymakla mükelleftir. Yalnız bu şartların mudaribin haklarını elinden almayan cinsten olması gerekmektedir (Şekerci, 1981, s. 280-281). Bu sebeple söz konusu şartlar bazı hususlar ile sınırlandırılmıştır. Bu sınırlandırmalara örnekler şu şekilde verilebilir. Sermayedar gerçekleşecek ortaklı̆̆ın süresinin belirli bir zamanda olmasına, gerçekleşecek faaliyetin konusunu belirli ürünlerde yapılmasına veya faaliyetin belirli şehirlerde kalmasına dair sınırlandırmalar koyabilir. Belirlenen sınırların dışına çıkılması mudaribin şözleşmeye uymadığı ve oluşacak zararı tazmin etmesi gerektiği anlamı taşımaktadır (Ebussuûd, s. 178).

Mudarib mukayyet mudarebede sözleşmenin gerektirdiği şartlar dairesinde, mutlak mudarebede ise ticari teâmüllerin çizdiği sınırlar içerisinde her türlü ticari faaliyeti yapabilme hürriyetine sahiptir. Örneğin; malı satıp kâr elde edebilir, peşin veya veresiye olarak mal satın alabilir, üçüncü bir şahsa mal alım satımı için vekalet verebilir, alışveriş yapmak amacıyla başka bir şehre yolculuk yapabilir. Burada dikkat edilmesi gereken husus; Rabbü'l-mâl mudaribe malları istediği şekilde tasarruf edebileceğini söylese dahi mudaribin İslam hukukuna ve örfe aykırı eylemlerden kaçınmak zorunda olduğudur (Kallek, 2005, s. 361).

\section{LITERATÜR TARAMASI}

Mudarebe, İslami finansı kavramsal olarak ele alan tüm temel iktisadi ve fikhi eserlerde bir başlık olarak ele alınmaktadır. Ancak bu taramada konunun özel olarak incelendiği çalışmalar sıralanmıştır. Mudarebeye ilişkin literatür incelendiğinde konunun genel olarak yöntemin anlaşılmasını kolaylaştırıcı çalışmalardan oluştuğu görülmektedir. Bu kapsamda önemli olduğu düşünülen bazı araştırmalar aşağıdaki şekilde özetlenmiştir:

Gedikli (1996) “XVI. ve XVII. Asır Osmanlı Şer'iye Sicillerinde Mudârebe Ortaklı̆̆ı: Galata Örneğg̈" isimli doktora çalışmasında öncelikle şirket kurumundan ve İslam hukukunda şirketlerden bahsederek mudarebenin tarihçesini ele almıştır. Çalışmanın sonraki bölümlerinde mudarebe kavramsal olarak geniş şekilde ele alınarak Galata örneği verilmiştir. Yazar, Osmanlı'da mudarebenin hem Müslüman hem de gayrimüslimler tarafından yoğun biçimde uygulandığını, toplumun her kesiminden insanların bu muameleye iştirak ettiğini ve İstanbul'da gemi ticaretinin en yoğun olduğu Galata da gelişme gösterdiğini ifade etmektedir. Ayrıca ilginç bir veri olarak yazarın değerlendirmeye tabi tuttuğu (arşiv kayıtları) mudarebe sözleşmelerinde kazancın ne şekilde paylaşılacağı hususunda net bir oran belirtilmemektedir. Kârın umumiyetle taraflarca yarı yarıya paylaşılmasını ifade eden tutarların kaydedildiğini belirtmişsir. Çalışma mudarebeye ilişkin en tafsilatlı kaynaklardan kabul edilebilir. Nitekim yazar ilgili çalışmayı "Osmanlı Şirket Kültürü - 16. - 17. Yüzyıllarda Mudarebe Uygulaması" adıyla kitaplaştırmıştır.

Gönen (2005) "İslam Hukukunda Mudarebe (Emek+Sermaye) Şirketinde Tarafların Hak ve Borçları" isimli çalışmasında Mudarebeyi hukuki açıdan inceleyerek Mudarebe şirketinde tarafların hak ve borçları üzerinde durmuştur. Çalışmanın ilk bölümünde İslam Hukukunda tesis edilen tüm şirketlere değinilerek Mudarebe şirketi üzerinde daha geniş olarak durulmuştur. Çalışmanın aslını oluşturan ikinci bölümde ise rabbü'l-mâl ve mudaribin hak ve borçlarından bahsedilmiş̧ir. Rabbü'l-mâl bahsinde sermaye koyma borcu, kardan payına düşeni talep etme hakkı ve avans hakkı incelenmiştir. Mudarib bahsinde ise sermayeyi işletme borcu, kardan payına düşeni talep etme hakkı, mudarebenin sınırlandırılması durumunda buna uyma borcu ve masrafları talep etme hakkı konularına değinilmiştir.

Özsoy (2012) hazırlamıș olduğu “Săglam Bankacıllk Modeli ile Katılım Bankacıllğına Giriş" kitabının beşinci bölümünde mudarebenin katılım bankalarında neredeyse hiç kullanılmadığını ifade etmektedir. Türkiye'de

\footnotetext{
${ }^{5}$ Zeylaî, age, IV, 113-115., Mâlik, Muvatta’, Krâz, 1.
} 
mudarebenin önünde çeşitli engellerin olduğunu vurgulayarak şu başlıklar ifade edilmiştir. Vade uyumsuzluğu: katılım bankaları kısa vadeli mevduat toplarken mudarebede kazanımlar 3 ile 5 yıl içerisinde alınmaktadır. Yasal altyapı: ülkede mudarebe için yasal altyapı yeterince uygun değildir. Teknik nedenler: mudarebe yönteminin uygulamak katılım bankaları için diğer yöntemlere nazaran daha zahmetlidir. Kayıt dışı Ekonomi: ülkede kayıt dışı ekonominin had safhalarda izlenmesi nedeniyle faaliyetlerin mudarib tarafından eksiksiz biçimde belgelendirilmesini imkânsız hale getirmektedir.

Çelik (2017) “Meşru’ Bir Yatırım Aracı Olarak Mudarebe ve Günümüzde Kullanımı” isimli çalışmada mudarebeyi kavramsal olarak incelemiş akabinde günümüzde katılım bankalarında daha yoğun kullanılması adına bazı önerilerde bulunmuştur. Yazar mudarebe finansmanının katılım bankalarında daha yoğun uygulanabilmesi için taraflara güvence sağlayacak bir mevzuatın hayata geçirilmesi gerektiğini, mudarebe işlemlerinden doğan ek vergilerin ortadan kaldırılmasının faydalı olacağını, yatırımlar için daha uygun bir ekosistem oluşturmasını ve mudarebe işlemlerini yapabilecek nitelikli çalışanların yetiştirilmesi gerektiğini ifade etmektedir.

Canbaz (2019) “Katılım Bankaları Borçluluğa mı, Reel Ekonomiye mi Katkı Yapmalı?” isimli çalışmasında katılım bankalarında kar-zarar ortaklıklarının neden kullanılmadığına ilişkin tepe yöneticiler ile bir analiz gerçekleştirmiştir. Toplam 16 katılım bankası çalışanı ile odak grup görüşmesi şeklinde yapılan uygulamada kar-zarar ortaklıklarının neden yapılmadığına ilişkin araştırma bulguları özetle şu şekildedir: Güvensizlik başlığ 1 altında müşterilere ve muhasebe sistemlerine olan güvensizliğe, hesap sahiplerinin sabırsızlığına, riske düşmeden kâr beklentisine, müteşebbis firmaların hesaplarının kısmen kayıt dışı olmasına, haram-helâl şuurunun zayıflamasına, iş dünyasında emanet ve ahde vefa kavramlarının ortadan kalkması gibi konulara işaret edilmiştir. Zihinsel değişim ve hassasiyetlerin kaybolması başlı̆̆ altında özel finans kurumları olmaktan çıkarak banka hüviyeti kazanılması akabinde İslami fonlama anlayışından salt kar beklentili kredi verme anlayışına geçildiği ifade edilmektedir. Katılımcılar bu değişimi İslami hassasiyetin kaybolması ve dünyevileşme olarak özetmemişlerdir. Yönetim ve sahiplerin kâr hırsı başlı̆̆ı altında kar beklentisi nedeniyle yönetimlerin daha hırslı olduğu ve şubelerin karlılığında kolay elde edildiği murabahaya yöneldiği ifade edilmektedir. Kaynak sorunu başlığ1 altında mevduatların kısa vadeli toplandığı ortaklıkların uzun vadeli yatırımlar olduğu ifade edilmektedir. Son başlık olarak diğer faktörler altında vergi dezavantajları ve operasyon süreçlerinin uzunluğu gibi nedenlerle ortaklıklardan daha kolay kar getiren yöntemlere tevessül edildiği kaydedilmiştir.

İnanır (2020) “16. ve 18. Asırlarda Osmanlı Fetva Literatüründe Mudârebe Ortaklı̆̆l” isimli çalışında 16. ve 18. asırlarda Osmanlı fetvalarında mudarebe ortaklı̆̆ını incelemiştir. Çalışmada mudarebe muamelesi sonucunda ortaya çıkan takyid, tarafların anlaşmazlığına sebebiyet veren iddialar, yaşanan sorunlar, zarar ve kârın paylaşımı gibi konular üzerinde durulmuştur. Yazar mudarebeye ilişkin fetvaların uygulamada çıkan sorunlardan ve serdedilen çözümlerden oluştuğunu ifade etmektedir. İncelediği metinler itibariyle mudarebenin özellikle ticaret yapma imkânı olmayan kimseler tarafından tercih edildiğini, mudarebe ortaklığında yaşanan sorunların genel itibarla mudaribin aktif rabbü'l-mâlin ise pasif ortak olmasından kaynaklandığını belirtmektedir. Ek olarak bu durumun diğer İslami finans yöntemlerine nazaran mudarebenin fetvaya daha çok konu olmasına neden olduğunu savunmaktadır. Yazar, Gedikli'ye benzer şekilde mudarebenin daha çok denizciliğin yoğun yapıldığ alanlarda geliştiğini Akdeniz/Karadeniz havzalarında tarım ve ticarete yönelik olarak yapıldığını ifade etmektedir.

Riduwan ve arkadaşları (2020) yapmış olduğu çalışmada Endonezya'da Islamic Rural Banks (BPRS) tarafından uygulanan mudarebe finansmanında alınan teminatlar üzerinde durarak ilgili süreçte karşılaşılan sorunlar üzerinde durmuştur. Çalışmanın sonuçlarına göre geleneksel mudarebede olmayan teminat meselesi İslami bankaların piyasalarda karşı karşıya olduğu yüksek risk seviyesi nedeniyle teminat alınması uygulanmasına hala ihtiyaç olduğu yönündedir. Mudarebe konusunda geleneksel fikıhta teminata izin verilmezken National Sharia Council (DSN) tarafından mudaribin idari ve teknik olarak yükümlülüklerini yerine getirmesini sağlamak amacıyla bankaların teminat alımlarına fetva verilmiştir. $\mathrm{Bu}$ fetva çalışmada tartışılarak altında yatan mesnetler eleştirilmiştir. Sonuç olarak yazarlarca; alınan teminatların finansmanı mı garanti altına aldığı yoksa mudaribin taahhütlerini yerine getirmesini mi sağladığ 1 konusunun ayırt edilmesinin zor olduğu vurgulanmıştır.

\section{VERI VE METODOLOJI}

Araştırmanın evreni katılım bankalarında geçmişte çalışanlar, hali hazırda çalışanlar ve İslam İktisadı ve Finansı alanında çalışan bireyler olarak belirlenmiştir. Bu kapsamda örneklem olarak ise Türkiye'nin farklı şehirlerinden toplamda 183 bireyden veri elde edilmiştir. Veriler anket yöntemiyle toplanmış ve bu süreçte telefon, e-posta, sosyal medya, yüz yüze görüşmelerle araştırma hakkında bilgi verilerek anketlerin cevaplanması sağlanmıştır. Katılımcılar benzer görevlerle iştigal etmiş veya etmekte olan bireyler olmaları nedeniyle örneklem homojen bir yapı sergilemektedir. Bu durum özel bir konuda yapılan araştırma sonuçlarının daha güvenilir olmasını sağlamak adına bilhassa planlanmıştır. Araştırma sürecinde 183 anketten 21 tanesi katılım bankalarında 
tecrübe yoksunluğu ve diğer tutarsızlıklar nedeniyle analize dahil edilmemiştir. Çalışmada güvenilir 161 anket verisi kullanılmıştır.

Literatürde mudarebenin önündeki engellere ilişkin herhangi bir ölçek tespit edilememiştir. Bu nedenle ölçek yazarlar tarafından geliştirilmiştir. Araştırma ölçeğinin hazırlanması aşamasında ankete dahil edilecek nedenlerin güvenilir ve gerçekçi olması adına birçok katılım bankası çalışanı ile istişareler gerçekleştirilmiştir. Ek olarak literatür incelenerek mudarebenin önünde engel teşkil ettiği varsayılan nedenler anket içeriğine dahil edilmiştir. Anket formu 3 bölümden oluşmakta olup ilk bölümde demografik özelliklere, ikinci bölümde katılım bankacılığına ilişkin sorular yer alırken son bölümde ise mudarebenin uygulanmasının önündeki engellere ilişkin nedenler sıralanmıştır. Bu kapsamda belirlenen 31 adet neden 5'li likert ölçeğiyle hazırlanan anket formuyla katılımcılara sunularak değişkenlerin kanaatlerinde oluşan önemlerine binaen puanlanması talep edilmiştir. Bu puanlamada 1- Hiç önemli değil, 2-Önemli Değil, 3- Orta Dereceli Öneme Sahip, 4- Önemli ve 5 - Çok önemli olacak şekilde kurgulanmıştır.

Araştırmanın analiz aşamasında öncelikle İstatistik Paket Programı ile demografik özelliklere ve mudarebenin uygulanmasının önündeki engellere ilişkin nedenlere frekans analizi uygulanmış tanımlayıcı ve açıklayıcı sonuçlar elde edilmiştir. Ardından ikincil aşamada mudarebenin uygulanmasının önündeki engellere ilişkin nedenlere faktör analizi uygulanmıştır. Faktör analizi sonucunda tüm nedenler 6 önemli faktör altında toplanmıştır. Oluşturulan ölçeğe güvenilirlik testi uygulanmış ve Cronbach's Alpha $(\alpha)$ iç tutarlılık katsayısının 0,958 olduğu tespit edilmiştir. Ardından verilerin faktör analizine uygun olup olmadığına ilişkin olarak KMO and Bartlett's Testi uygulanmış ve Faktör analizi ölçütlerine göre $(0,90<\mathrm{KMO}<0,70=$ İyi) verinin analize uygun olduğu anlaşılmıştır (Field, 2013). Bu analizler sonucunda ölçeğin araştırmanın sonuçlarına ulaşmada güvenilir ve geçerli bir ölçek olduğu ifade edilebilir. Test sonuçları ve mudarebenin önünde engellere ilişkin ölçek aşağıdaki şekilde tasarlanmıştır.

Tablo 1. Mudarebe Ölçeği Güvenilirlik ve KMO and Bartlett's Testi

\begin{tabular}{|c|c|c|c|}
\hline & & $\begin{array}{l}\text { Kaiser-Meyer-Olkin Measure of Sampling Adequacy. } \\
\text { Bartlett's Test of Sphericity Approx. Chi-Square }\end{array}$ & $\begin{array}{r}, 781 \\
5421,610\end{array}$ \\
\hline Cronbach's Alpha & $\mathrm{N}$ of Items & df & 465 \\
\hline 0,958 & 31 & Sig. &, 000 \\
\hline
\end{tabular}

Tablo 2. Mudarebenin Önünde Engel Teşkil Ettiği Düşünülen Değişkenler

\begin{tabular}{|l|l|}
\hline & $\begin{array}{l}\text { Katılım } \\
\text { Mudarebe Finansmanı Uygulanmasında Engeller }\end{array}$ \\
\hline $\mathbf{1}$ & Yatırımın gelecekte başarısız olacağına dair kanaat \\
\hline $\mathbf{2}$ & Müteşebbise duyulan güvensizlik \\
\hline $\mathbf{3}$ & Müteşebbisin yatırım konusunda ehil olmaması \\
\hline $\mathbf{4}$ & Piyasaların mudarebede ortaya çıkan riski almaya uygun olmaması \\
\hline $\mathbf{5}$ & Mudarebenin yüksek riskli bir ortaklık oluşu \\
\hline $\mathbf{6}$ & Mudarebede vade belirsizliği \\
\hline $\mathbf{7}$ & Likidite riskine neden olması \\
\hline $\mathbf{8}$ & Mudarebede var olan düşük garanti faktörü \\
\hline $\mathbf{9}$ & Mudarebede teminat alamama faktörü \\
\hline $\mathbf{1 0}$ & Mudarebede prosedürün zorluğu \\
\hline $\mathbf{1 1}$ & Karın ne kadar olacağını öngörememek \\
\hline $\mathbf{1 2}$ & Ne zaman kar edileceğini bilememek \\
\hline $\mathbf{1 3}$ & Katılım bankalarının yatırmış olduğu tutarların tümüyle batma ihtimali \\
\hline $\mathbf{1 4}$ & Mudarebe taleplerinde uzman personel ihtiyacı \\
\hline $\mathbf{1 5}$ & Farklı sektörlerden gelebilecek mudarebe finansmanı taleplerinin tam anlamıyla analiz edilememesi \\
\hline $\mathbf{1 6}$ & Mudarebede desteklenen yatırım hakkında yanlış karar verme ihtimali \\
\hline $\mathbf{1 7}$ & Mudarebe talepleri nedeniyle ek maliyetler (danışmanlık, işleyiş, personel vs.) \\
\hline $\mathbf{1 8}$ & Mevzuatın uygun olmaması \\
\hline $\mathbf{1 9}$ & Mudarebe işlemlerinin vergiye tabi olması \\
\hline $\mathbf{2 0}$ & İşlemi yapacak nitelikli personel olmayışı \\
\hline $\mathbf{2 1}$ & Murabaha finansmanında var olan yüksek garanti faktörü \\
\hline
\end{tabular}




\begin{tabular}{|l|l|}
\hline $\mathbf{2 2}$ & Murabaha finansmanında var olan düşük risk faktörü \\
\hline $\mathbf{2 3}$ & Murabaha finansmanında var olan teminat alma faktörü \\
\hline $\mathbf{2 4}$ & Murabaha finansmanında var olan prosedür kolaylığı \\
\hline $\mathbf{2 5}$ & Finanse edilen firmanın elde ettiği kârın kontrol edilmesindeki riskler \\
\hline $\mathbf{2 6}$ & Kredi riski \\
\hline $\mathbf{2 7}$ & Elde edilecek muhtemel karın düşük olması \\
\hline $\mathbf{2 8}$ & Mudarebe ortaklı̆̆ yapılacak nitelikli projelerin olmayışı \\
\hline $\mathbf{2 9}$ & Nitelikli girişimci olmayışı \\
\hline $\mathbf{3 0}$ & Girişimcilik ekosisteminin gelişmemiş olması \\
\hline $\mathbf{3 1}$ & Yeterli öz kaynağın olmayışı \\
\hline
\end{tabular}

\section{ARASTTIRMA BULGULARI VE ANALIZLER} şekildedir.

Katılımcıların demografik özelliklerine ilişkin kısa bilgiler ve verilere ilişkin çıkarımlar aşağıdaki

Tablo 3. Demografik Özelliklere İlişkin Frekans Dağılımları

\begin{tabular}{lll} 
Yaş Grupları & Sayı & $\mathbf{\%}$ \\
\hline 19-25 Arası & 19 & 12 \\
26-30 Aras1 & 17 & 11 \\
31-35 Aras1 & 27 & 17 \\
36-41 Aras1 & 60 & 37 \\
42 ve Üzeri & 38 & 24
\end{tabular}

\begin{tabular}{lll} 
Ĕgitim & Sayı & $\mathbf{\%}$ \\
\hline Lisans & 101 & 63 \\
Yüksek Lisans & 42 & 26 \\
Doktora & 18 & 11 \\
& &
\end{tabular}

\begin{tabular}{lll} 
Pozisyon & Sayı & $\mathbf{\%}$ \\
\hline Ast Çalışan & 64 & 40 \\
Orta Düzey Yönetici & 93 & 58 \\
Üst Düzey Yönetici & 4 & 2
\end{tabular}

\begin{tabular}{lll} 
Cinsiyet & Sayı & \% \\
\hline Kadın & 32 & 20 \\
Erkek & 129 & 80
\end{tabular}

\begin{tabular}{lll} 
Mesleki Deneyim & Sayı & \% \\
\hline 1-5 Y1 & 39 & 24 \\
6-10 Y11 & 36 & 22 \\
11-15 Y11 & 53 & 33 \\
16-20 Y1 & 28 & 17 \\
21 Y1 ve üzeri & 5 & 3
\end{tabular}

Örneklemin yaş grupları incelendiğinde \%61'nin 36 yaş ve üzerinde olduğu görülmektedir. Mesleki deneyim açısından incelendiğinde ise katılımcıların \%53'ünün katılım bankalarında 10 yıldan fazla çalıştıkları görülmektedir. Bu iki veri ortak olarak irdelendiğinde ise analize konu örneklemin çalışma hayatlarının uzmanlık dönemlerinde olduğu araşıırma sonuçlarına güvenilir veri sağlayacakları anlaşılmaktadır. Öte yandan daha önce mevduat bankalarında çalışmış \%21'lik katılımcı her iki bankacılık anlayışını değerlendirebilecek niteliktedir.

Örneklemin \%80'i erkek \%20' si ise kadın katılımcılardan oluşurken İslami bankacılık sektörünün (verinin kısıtlı bir açıklama gücü olduğunu da unutmadan) erkek yoğun bir sektör olduğu düşünülebilir. Sektörün eğitim seviyesi beklendiği gibi yüksektir. \%63 lisans, \%26 yüksek lisans ve \%11 doktora yapmış çalışanlardan oluşmaktadır.

Örnekleme dahil olan uzmanlardan demografik bilgilerin alınması akabinde katılım bankacıllı̆ı ve sektörün uygulamalarına ilişkin bazı konular üzerinden görüşleri talep edilmiştir. Bu sorulara verilen yanıtlar katılım bankalarının imajları ve uygulamalarının yansımaları hakkında kritik bilgiler sağlamaktadır. Katılımcılara yöneltilen sorular ve frekans analizi aşağıdaki şekildedir. 
Tablo 4. Katılım Bankacılığına İlişkin Bazı Görüşler

Katılım bankalarının geleneksel bankalardan tamamen farklı olduğunu düşünüyorum

Sayı $\%$

\begin{tabular}{lll} 
Katılmiyorum & $\mathbf{1 6}$ & $\mathbf{9 , 9}$ \\
Kararsizım & $\mathbf{2 8}$ & $\mathbf{1 7 , 4}$ \\
Katıliyorum & 71 & 44,1 \\
Kesinlikle & 46 & 28,6 \\
Katıliyorum & 4 \\
\hline
\end{tabular}

Katılım bankalarının riskin paylaşımına yeterince katıldığını düşünüyorum

\begin{tabular}{lll} 
& Sayı & $\mathbf{\%}$ \\
\hline Kesinlikle & $\mathbf{1 3}$ & $\mathbf{8 , 1}$ \\
Katılmıyorum & $\mathbf{2 5}$ & $\mathbf{1 5 , 5}$ \\
Katılmiyorum & $\mathbf{4 1}$ & $\mathbf{2 5 , 5}$ \\
Kararsızım & 58 & 36,0 \\
Katıliyorum & 24 & 14,9 \\
Kesinlikle & 24 \\
Katıliyorum & & \\
\hline
\end{tabular}

Mudarebe finansmanının daha yoğun

kullandırılması gerektiğine inanıyorum.

\begin{tabular}{lll} 
& Sayı & $\mathbf{\%}$ \\
\hline Kesinlikle & 1 &, 6 \\
Katılmiyorum & 10 & 6,2 \\
Katılmiyorum & 35 & 21,7 \\
Kararsizım & $\mathbf{6 6}$ & $\mathbf{4 1 , 0}$ \\
Katılıyorum & $\mathbf{4 9}$ & $\mathbf{3 0 , 4}$ \\
Kesinlikle & & \\
Katılıyorum & & \\
\hline
\end{tabular}

\begin{tabular}{|c|c|c|}
\hline \multicolumn{3}{|c|}{$\begin{array}{l}\text { Katılım bankalarında finansman } \\
\text { alternatiflerinin yeterli olduğunu düşünüyorum }\end{array}$} \\
\hline & Sayı & $\%$ \\
\hline Kesinlikle & 3 & 1,9 \\
\hline Katılmiyorum & 45 & 28,0 \\
\hline Kararsizım & 42 & 26,1 \\
\hline Katıliyorum & 53 & 32,9 \\
\hline Kesinlikle Katıliyorum & 18 & 11,2 \\
\hline
\end{tabular}

Katılım bankacılı̆̆ında Murabahanın yoğun yapılması beni huzursuz etmektedir

\begin{tabular}{lll} 
& Sayı & $\mathbf{\%}$ \\
\hline Kesinlikle & 14 & 8,7 \\
Katılmıyorum & 32 & 19,9 \\
Katılmiyorum & $\mathbf{4 3}$ & $\mathbf{2 6 , 7}$ \\
Kararsızım & $\mathbf{4 3}$ & $\mathbf{2 6 , 7}$ \\
Katılıyorum & $\mathbf{1 8 , 0}$ \\
Kesinlikle Katılıyorum & $\mathbf{2 9}$ & $\mathbf{}$ \\
\hline
\end{tabular}

Katılımcıların \%27,3’ü katılım bankalarının mevduat bankalarından tamamen farklı olmadığını düşünmektedir. \%21 katılımcının mevduat bankalarında çalışmış olmasının bu oranı etkilemiş olması muhtemeldir. Ancak verinin katılım bankacılığı uzmanlarından elde edildiği dikkate alındığında yüksek olduğu vurgulanmalıdır. Uzmanlar nazarında oluşan bu oranın halkın nazarında daha da yüksek olması gayet tabiidir. Katılım bankalarının bu noktada imajları ve misyonları hakkında daha çok çaba göstermeleri gerekmektedir.

Katılımcıların \%56'sı kredi/finansman seçeneklerinin yetersiz olduğunu düşünürken bu veriye paralel olarak \%49 katılımcı ise katılım bankalarının riskin paylaşımına yeterince katılmadığını düşünmektedir. Katılım bankalarında en yoğun kullandırılan murabaha finansmanı riskin düşük olduğu bir ürün olarak dikkat çekmektedir. Sürekli olarak tartışılan bir ürün olan murabaha hakkında katılımcılar \%71 oranında sektörde bu kadar yoğun kullanılmasından rahatsız olduklarını ifade etmişlerdir. Katılım bankalarında neredeyse hiç göremediğimiz mudarebe finansmanının ise \%71 oranında finansman alternatifi olarak sunulması gerektiği yönünde görüş bildirmişlerdir. Bu sonuçlardan da katılım bankalarının risk paylaşımı söylemlerinin uzmanlarca dahi anlamlı karşılık bulmadığı anlaşılmaktadır.

\section{MUDAREBE FİNANSMANININ ÖNÜNDEKİ ENGELLER}

Toplanan verilere yapılan faktör analizi neticesinde mudarebenin katılım bankalarında uygulanmamasının nedenleri 6 faktör altında toplanmıştır. Katılımcılara yöneltilen 31 değişkenden 2 tanesi herhangi bir faktöre yüklenememeleri nedeniyle analizden çıkarılmıştır. Son aşamada oluşan faktörler risk ile ilgili nedenler, girişimcilik ekosistemi ile ilgili nedenler, proje kârt ile ilgili nedenler, çalışanlara bağlı nedenler, mevzuat ile ilgili nedenler ve müteşebbislere bağlı nedenler olarak sıralanmıştır. 
Tablo 5. Mudarebe Finansmanının Önündeki Engeller Faktör Analizi

\begin{tabular}{|c|c|c|c|}
\hline \multirow{2}{*}{\multicolumn{2}{|c|}{ 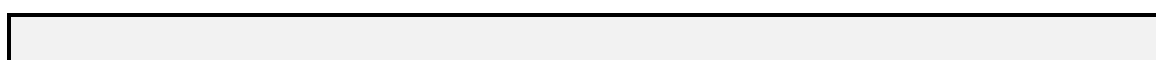 }} & \multirow{3}{*}{$\begin{array}{l}\text { Faktör } \\
\text { Yükleri }\end{array}$} & \multirow{3}{*}{$\begin{array}{l}\text { Varyans } \\
\text { Açıklama } \\
\text { Oranları } \\
\% \\
\end{array}$} \\
\hline & & & \\
\hline Faktörler & Faktör Bileşenleri & & \\
\hline \multirow{7}{*}{$\begin{array}{l}\text { Risk ile İlgili } \\
\text { Nedenler }\end{array}$} & Murabaha finansmanında var olan teminat alma faktörü & 0,81 & \multirow{7}{*}{46,17} \\
\hline & Murabaha finansmanında var olan yüksek garanti faktörü & 0,80 & \\
\hline & Murabaha finansmanında var olan düşük risk faktörü & 0,79 & \\
\hline & Murabaha finansmanında var olan prosedür kolaylığ & 0,61 & \\
\hline & Mudarebede var olan düşük garanti faktörü & 0,59 & \\
\hline & Kredi riski & 0,54 & \\
\hline & Mudarebede teminat alamama faktörü & 0,55 & \\
\hline \multirow{4}{*}{$\begin{array}{l}\text { Girişimcilik } \\
\text { Ekosistemi ile } \\
\text { İlgili Nedenler }\end{array}$} & Nitelikli girişimci olmayışı & 0,90 & \multirow{4}{*}{8,68} \\
\hline & Nitelikli projelerin olmayışı & 0,86 & \\
\hline & Girişimcilik ekosisteminin gelişmemiş olması & 0,74 & \\
\hline & $\begin{array}{l}\text { Piyasaların mudarebede ortaya çıkan riski almaya uygun } \\
\text { olmaması }\end{array}$ & 0,47 & \\
\hline \multirow{7}{*}{$\begin{array}{l}\text { Proje Kârı ile } \\
\text { İlgili Nedenler }\end{array}$} & Karın ne kadar olacağını öngörememek & 0,80 & \multirow{7}{*}{6,78} \\
\hline & Ne zaman kar edileceğini bilememek & 0,76 & \\
\hline & Mudarebenin yüksek riskli bir ortaklık oluşu & 0,74 & \\
\hline & Mudarebede vade belirsizliği & 0,72 & \\
\hline & $\begin{array}{l}\text { Katılım bankalarının yatırmış olduğu tutarların tümüyle } \\
\text { batma ihtimali }\end{array}$ & 0,66 & \\
\hline & Likidite riskine neden olması & 0,65 & \\
\hline & Elde edilecek muhtemel karın düşük olması & 0,58 & \\
\hline \multirow{5}{*}{$\begin{array}{l}\text { Çalışanlara Bağlı } \\
\text { Nedenler }\end{array}$} & İşlemi yapacak nitelikli personel olmayışı & 0,78 & \multirow{5}{*}{6,32} \\
\hline & Mudarebe taleplerinde uzman personel ihtiyac1 & 0,76 & \\
\hline & \begin{tabular}{|l} 
Farklı sektörlerden gelebilecek mudarebe finansmanı \\
taleplerinin tam anlamıla analiz edilememesi
\end{tabular} & 0,64 & \\
\hline & $\begin{array}{l}\text { Mudarebede desteklenen yatırım hakkında yanlış karar verme } \\
\text { ihtimali }\end{array}$ & 0,42 & \\
\hline & $\begin{array}{l}\text { Mudarebe talepleri nedeniyle ek maliyetler (danışmanlık, } \\
\text { operasyonel, çalışan vs.) }\end{array}$ & 0,55 & \\
\hline \multirow{3}{*}{$\begin{array}{l}\text { Mevzuat ile İlgili } \\
\text { Nedenler }\end{array}$} & Mudarebede prosedürün zorluğu & 0,79 & \multirow{3}{*}{5,31} \\
\hline & Mudarebe işlemlerinin vergiye tabi olması & 0,65 & \\
\hline & Mevzuatın uygun olmaması & 0,59 & \\
\hline \multirow{3}{*}{$\begin{array}{l}\text { Müteşebbislere } \\
\text { Bağlı Nedenler }\end{array}$} & Yatırımın gelecekte başarısız olacağına dair kanaat & 0,80 & \multirow{3}{*}{3,97} \\
\hline & Müteşebbisin yatırım konusunda ehil olmaması & 0,50 & \\
\hline & Müteşebbise duyulan güvensizlik & 0,77 & \\
\hline \multicolumn{3}{|l|}{ TOPLAM } & 77,23 \\
\hline
\end{tabular}

\subsection{Risk ile İlgili Nedenler}

Riskle ilgili nedenler faktörü incelendiğinde murabaha yönteminin mudarebenin uygulanmasında olumsuz etkisi ortaya çıkmaktadır. Murabahanın katılım bankaları açısından kolay uygulanan, teminatlandırılan ve düşük riskli bir yöntem olması varyans açıklama oranlarına göre mudarebenin uygulanmasının önündeki en büyük engel olarak ifade edilebilir. Diğer yandan bu veri risk paylaşımı iddiasında bulunan katılım bankalarının riske girmek noktasında iştahlı olmadıklarını açıkça ortaya koymaktadır. Katılım bankaları mudarebede ortaya çıkan yüksek risk ve yüksek kara odaklanmaktan ziyade düşük riskli yöntemlerle düşük karlar ile çalışmayı tercih etmektedirler. Mudarebe açısından menfi bir tablo olan bu kaçınmanın ortadan kaldırılması adına faizsiz finansman mevzuatının detaylandırılması gerekmektedir. Mudarebe gibi yöntemlerin metodolojisinin belirlenerek piyasalarda oluşan yüksek risk algısının mümkün olduğunca düşürülmesi veya bertaraf edilmesi gerekmektedir. Piyasalarda yüksek risk ihtiva etmesine karşın yüksek oranda yatırım yapılan alternatif yatırım araçlarının varlığı mudarebenin önündeki riske dair soru işaretlerinin yetersiz enformasyon kaynaklı olduğunu düşündürmektedir. Ek olarak bu faktörün etkisinin azaltılması adına bazı değişimlere ihtiyaç bulunmaktadır. Bunlar; yatırım ve ortaklık finansmanına girmek için katılım bankalarının uzun vadeli mevduat yapısına, mudarib olacak bireylerin 
ticaret ahlakına, ülkenin büyük ölçüde kayıtlı işleyen bir ekonomiye, siyasî ekonomik istikrara ve en önemlisi geleceğin öngörülebilirliğine sahip olması gerekmektedir.

\subsection{Girişimcilik Ekosistemi ile İlgili Nedenler}

Mudarebenin önündeki ikinci en büyük engel Türkiye'de henüz gelişme gösterememiş girişimcilik ekosistemi olarak belirlenmiştir. Katılımcılar nitelikli girişimcilerin ve projelerin olmadığını, bu nedenle bu tip bir riski almaya uygun ekosistemin olmadığını ifade etmişlerdir. Girişimcilik ekosistemi müteşebbislerin kendi işlerini kurabilmeleri için gerekli olan sosyal ve ekonomik zemini ifade etmektedir. İlgili sistem müteşebbislere birbirleri ile uyumlu bir şekilde çalışan bazı değiş̧enleri sunmalıdır.

Bu kapsamda Türkiye'de girişimcilik ekosisteminin geliștirilmesi adına izleyen unsurların geliștirilmesi ve gerekli düzenlemelerin yapılması gerekmektedir. Bunlar; girişimcilik finansmanı ve finansmana erişim, devlet politikaları, kamu girişimcilik programları, girişimcilik eğitimi, araştırma, geliştirme ve teknoloji transferi, ticari ve yasal altyapı, pazarın açıklığı, fiziksel altyapı, kültürel ve sosyal normlar (Cohen \& Winn, 2007)

\subsection{Proje Kârına Bağlı Nedenler}

Üçüncü önemli faktör mudarebeye konu projelerden elde edilecek kâr ile ilgili belirsizlikler olarak ifade edilebilir. Mudarebe finansmanında kârın hangi vadede ve ne kadar olacağını öngörememek ciddi bir engel olarak görülmektedir. Halbuki diğer tüm finansman yöntemlerinde vade sonunda katılım bankalarının ne kadar kâr elde edeceği hesaplanabilmektedir. Ek olarak ortaklığa konu sermayenin tümüyle batması ihtimali de atlanmamalıdır. Bu nedenler mudarebenin katılım bankaları açısından likidite riskine yol açan yüksek riskli bir finansman yöntemi olduğunu göstermektedir. Bu doğrultuda katılım bankaları finansal rasyonalite (Soufian, Forbes, \& Hudson, 2014) dairesinde mudarebe yöntemini uygulamaktan ve kâr belirsizliğinden kaçınmaktadırlar.

Katılım bankaları günümüzde mudarebeyi bir finansman aracı olarak kullanmazken benzer bir yöntem olan müşarekeyi girişim sermayesi yatırım ortaklıkları şirketleri ile uygulamaktadırlar. Müşareke yöntemi her iki tarafın da sermayesiyle ortaklığa katılması nedeniyle mudarebeye nispetle düşük riskli olarak nitelendirilmektedir. $\mathrm{Bu}$ kanaatin altında sermayesini ortaya koyan müşterinin ortaklık hakkında daha çok çabalayacağ yatmaktadır. Müşareke temelli ortaklıklar kuran Ziraat Girişim Sermayesi Yatırım Ortaklığı A.Ş.'nin 2019 yılı yarısında açıkladıkları 73,5 Milyonluk kârları düşünüldüğünde mudarebe için de benzer bir karlılığa ulaşmanın mümkün olduğu düşünülmektedir (Ziraat Girişim Sermayesi Yatırım Ortaklığı A.Ş. , 2019). Bu aşamada çözüm olarak girişim sermayesi şirketleri üzerinden katılım bankaları alternatif mudarebe finansmanı uygulayarak girişimlerin karlılığını ölçebilirler.

\section{4. Çalışanlara Bağlı Nedenler}

Mudarebe finansmanı henüz katılım bankalarının şubelerinde uygulanabilen bir yöntem değildir. Mudarebeye konu projeler genel müdürlük seviyesinde değerlendirilerek karara bağlanmaktadır. Dolayısıyla şubelerde mudarebenin karara bağlanabilmesi mümkün değildir. Ayrıca mudarebe gibi ortaklık içeren bir finansman kararının da kolayca verilemeyeceği açıktır. Bu nedenler faktör analizinde bir diğer engel olarak karşımıza çıkmaktadır. Katılımcılar işlemi yapacak nitelikli çalışan olmayışını, farklı sektörlerden gelebilecek mudarebe finansmanı taleplerinin tam anlamıyla analiz edilememesini, yatırım hakkında yanlış karar verme ihtimalini ve oluşabilecek ek maliyetleri mudarebenin önündeki önemli engeller olarak ifade etmişlerdir.

$\mathrm{Bu}$ problemin suni bir problem olduğu aşılmak istendiği taktirde yöntemin uygulanmasında belirli sınırlandırmalar ve usuller ile rahatlıkla çözülebileceği düşünülmektedir. Çalışanlara verilen oryantasyon eğitimlerine benzer şekilde ilk etapta eğitimler düzenlenerek belirli sınırlarda mudarebe ortalıkları kurulması sağlanabilir. Tecrübenin tamam olduğu kanaati halinde ise sınırlandırmalar kaldırılarak sürecin daha geniş bir tabana yayılabileceği düşünülmektedir.

\subsection{Mevzuata Bağlı Nedenler}

Bir diğer önemli faktör mevzuat sorunu olarak karşımıza çıkmaktadır. Katılım bankaları diğer bankalar gibi bankacılık mevzuatına tabiidir. Bu nedenle temelde farklı olan bazı uygulamalar geleneksel banka uygulamaları gibi muamele görmektedir. Bu sorunun yanı sıra katılım bankalarının mevzuatı faizsizlik ilkesine göre tüm yöntemlerin nasıl uygulanacă̆ detaylandırılarak düzenlenmelidir. 2019'da katılım bankaları için "Faizsiz Bankacılık İlke ve Standartlarına Uyuma İliş̧kin Tebliğ" gibi mevzuat çalışmaları yapılsa da henüz uygulamada bir değişiklik söz konusu değildir. İlgili çalışmalarda tartışılan ve muğlaklık içeren noktalar olsa da 
sektörün uygulamasına olumlu katkılar yapacağı açıktır. Sektördeki uygulamalar ileride mevzuatta bazı değişiklikleri gerekli kılacaktır.

Önümüzdeki süreçte akademi, sektör ve düzenleyiciler arasındaki çalışmalar Türkiye'de İslami finansın sağlıklı bir şekilde yaygınlaşmasına ve uygulanmasına katkı sağlayacaktır (Çalışır, 2019).

\subsection{Müteşebbislere Bağlı Nedenler}

Mudarebenin önünde engel teşkil eden son ve en az etkili olan faktörün müteșebbislere bağlı nedenler olduğu görülmektedir. Değişkenlere daha detaylı bakıldığında ise yatırımın gelecekte başarısız olacağına dair kanaat, müteşebbisin yatırım konusunda ehil olmadığ 1 düşüncesi ve sonuç olarak müteşebbise duyulan güvensizliğin mudarebenin uygulanmasında engel teşkil ettiği anlaşılmaktadır.

Ortaya çıkan bu faktörün İslami finans kurumları açısından geçmiş tecrübelere uzanan olumsuz bir hikayesi bulunmaktadır. İslami finans kurumları ilk kuruldukları dönemlerde ortaklık temelli finansman ilişkilerine girdiler ancak sistemin henüz gelişmemiş olması, teminat konusundaki belirsizlikler, kurumların herhangi bir güvenceye sahip olmamaları ve ortaklık kurulan müşterilerin ahlaki problemleri gibi nedenlerle bu yöntemlerden uzaklaşarak murabaha ve finansal kiralama gibi vadeli satı usullerini tercihe etmeye başladılar. Hüsnü niyet ile girişilen ortaklıklar mudaribler tarafından suitimal edilmiş ve bu nedenle İslami finans kurumları ciddi zararlara uğramıștır. Müslüman bireyler olarak İslami finansı kasıtlı olarak tercih ettiği düşünülen müşterilerin yapmış oldukları usulsüzlükler ve finansal ahlaksızlıklar bütünüyle Katılım bankalarının finansman anlayışını değiştirmiştir. Esasında haklı gibi gözüken bu kötü tecrübeler katılım bankalarının düşük riskle düşük ancak sürekli kazanç sağlama fikrinin temellerini oluşturmuştur.

Günümüzde sistemli bir yapı haline gelen bankacılık kanununa tabi ve banka sıfatı taşıyan katılım bankalarının bu endişelerinin günümüz iktisadi gerçekleri bağlamında anlamlı olmadığı düşünülmektedir. Bankaların müşterilerini araştırmaları, tahkik etmeleri ve kredi tahsis konularında güvenilir bir süreç yönetimi bulunmaktadır. Bu sorunun pratikte çözülmesi katılım bankalarının sınırlı örneklerle ve düşük sermayeli ortaklıkla süreci deneyimlemesi vesilesiyle sağlanabilir. Toplumun iş ahlakının iyileştirilmesi ve kontrol altına alınmasının gerekliliği bu aşamada çokça zikredilse de bu ümidin ütopik bir beklenti olduğu açıktır. Uygulamaya girişilmediği taktirde geçmiş bir tramvaya bağlı olduğu düşünülen bu endişenin ortadan kaldırılması güç gözükmektedir.

\subsection{Diğer Nedenler}

Katılımcılara anket formunda verilen değişkenlerin yanı sıra mudarebe finansmanının uygulanmasının önünde ne tip engeller bulunduğuna dair kendi kanaatlerinin de ifade edilmesi istenmiştir. Bu minvalde 6 katılımcı ek görüş beyan etmiştir. İlgili görüşler değiştirilmeksizin aşağıdaki şekilde sıralanmıştır.

"Mudarebe katılım bankalarının değil yatırım şirketlerinin görevi olmalıdır. Katılım bankalarının varlık nedeni bankacılıktır. Yatırım değil. Katılım bankacılı̆̆l yüksek risk almaya uygun bir sistem değildir.”

"Burada en büyük problem güven meselesidir. Katılım bankaları sermayeyi işletmesi için emek sahiplerine teslim etmeye cesaret edemez. Diğer büyük engel ise kayıt dışı ekonomi, katılım bankaları koyduklarl sermayeyi tamamen kaybetme riski ile karşılaşıyor. Tabi kanun koyucusunun da yasal zemin konusunda yeterli ortamı oluşturmayışı mudarebenin önündeki en büyük engellerdir."

"Devletinin desteğinin yeterli olmaylşı. Mudarebede mevzuat sorunu. Faizsiz finansal düzenin temelden ele alınmasl gerekmektedir."

“Güven problemi. Şeffaf yatırımcı yok gibi. Kayıt dışı ekonomi had safhada. Ortaklık kültürünün olmayışı bir diğer engel (küçük olsun benim olsun)”

"Katılım Bankalarının kaynak vadelerinin Mudarebe finansmanı için uyumlu olmaması en büyük engeldir. Kısa vadeli mevduat toplama uzun vadeli finansmanı zorlaştırmaktadır”

"Mudarebe sadece katılım bankacılı̆̆ının bir misyonu olmamalıdır. Bankacılı̆̆ın asli görevleri arasında yer almalıdır. Ayrıca bankaların fizibilite ve projeksiyonlara verdiği önem ne yazık ki girişimcilerde bulunmamaktadır." 


\section{SONUÇ}

Mudarebe ortaklığı Kur'an-1 Kerim'de ticaretin teşvik edilmesi, Peygamberin sünneti ve mudarebe yaptığına dair sahih bilgiler münasebetiyle önemli bir finansal yöntem olarak kabul edilmektedir. Riskin taraflarca eşit düzeylerde paylaşıldığı yöntem cari çalışma hayatının ve girişimcinin desteklenmesine katkı yaparak sermaye ihtiyaçlarına da alternatif olabilecek bir finansman yöntemidir. Ancak yöntemin kullanılmasının hem bireyler arasında hem de kurumsal düzeyde yetersiz kaldığ 1 rahatlıkla söylenebilir. Bu bağlamda kurumsal mudarebenin uygulama alanı olan katılım bankalarının yöntemi uygulamak hususunda bazı sorunlar yaşadığı ve engellere maruz kaldığı görülmektedir. Bu çalışmada katılım bankalarının tüm faaliyetlerinde uygulandığını ifade ettiği yöntemin yatırım ortaklığı ekseninde neden uygulanamadığı veya tercih edilmediği üzerinde durulmuştur. Katılım bankacılığı uzmanlarından elde edilen verilere göre şu önemli sonuçlara varılmıştır;

Öncelikli olarak katılım bankaları mudarebeyi çok yüksek riskli bir finansman yöntemi olarak kabul etmektedir. Bu nedenle yatırım ortaklığı şeklindeki mudarebe finansmanını müşterilerine sunmamaktadırlar. Faktöre yüklenen önemli değişkenler incelendiğinde murabaha veya teverruk gibi düşük riskli alternatif finansman yöntemlerinin mudarebenin tercih edilmesinin önünde ciddi engel teşkil ettiği anlaşılmaktadır. Katılım bankaları teminat alamadıkları, vadeyi ön göremedikleri ve garanti bir kâr alamadıkları bir ortaklığı bankacılık sektörünün dinamikleri açısından uygulanamaz bulmaktadırlar. Likidite sorunu yaşamamak adına alınan kredi kararları neticesinde mudarebeden elde edilebilecek muhtemel yüksek karlar göz ardı edilmektedir. Nihai olarak katılım bankaları düşük risk ve düşük kar ile çalışmayı tercih etmektedirler.

İkinci önemli faktörde katılımcılar; Türkiye'de henüz girişimcilik ekosisteminin gelişmediğini, nitelikli girişimcilerin olmadığını ve yatırım yapılabilecek düzeyde projelerin gelmediğini ifade etmişlerdir. Bu sebeplere bağlı olarak ülkede mudarebeye uygun bir ekosistemin var olmadığı, müşterilerin desteklenemeyeceği ifade edilmiştir.

Üçüncü faktör, mudarebe finansmanın şubelerden yürütülmesi halinde değerlendirme yapabilecek düzeyde entelektüel bilgiye sahip çalışanlara olan ihtiyaçtır. Mudarebenin bir yatırım ortaklı̆̆ finansmanı olması nedeniyle karar sürecinin geleneksel kredilere nazarla hızlı olması mümkün değildir. İlgili finansman kararlarının ön aşamada şubelerde verilecek olması talepleri değerlendirebilecek nitelikte personele ihtiyaç olacağı veya danışmanlık hizmeti alınması gerektireceği sonucunu ortaya koymuştur. Bu durum ek çalışan maliyeti oluşturması hasebiyle mudarebenin önündeki bir diğer önemli faktör olarak görülmektedir.

Bir diğer faktör katılım bankacığına ilişkin faizsizlik ilkesine bağlı bir mevzuatın olmayışı ve tabi olunan mevzuatın İslami finans yöntemleri bağlamında yeterli düzeyde detaylandırılmamasıdır. Dolaysıyla katılımcılar, cari mevzuatın mudarebe yöntemini uygulamak hususunda henüz yeterli olmadığını düşünmektedirler.

Analizlerde son ve en düşük açıklama oranına sahip faktör; müteşebbislere ilişkin ortaya çıkan bazı soru işaretleridir. Son faktörün değişkenleri incelendiğinde katılım bankalarının projenin gelecekte başarısız olacağına dair öngörüsü, müteşebbisin yatırım konusunda ehil olmadığı kanaati ve müteşebbise duyulan güvensizlik mudarebenin önünde bir diğer önemli set olarak belirlenmiştir.

Sonuç olarak İslami bankacılıkta geçmişten günümüze çokça karşılaşılan riski paylaşma, ortaklık kurma ve reel sektörün (üretim ve ticaret) desteklenmesi gibi kavramların yüksek risk içeren mudarebe yöntemi bağlamında değerlendirilmediği anlaşılmıştır.

\section{KAYNAKÇA}

Aktepe, İ. E. (2017). Katılım Finans. İstanbul: TKBB Yayınları.

Canbaz, M. (2019). Katılım Bankaları Borçluluğa mı, Reel Ekonomiye mi Katkı Yapmalı? M. Dalkılıç (Dü.) içinde, Academic Studies on Social and Education Sciences (s. 198-220). Ankara: Gece Kitaplı̆̆1.

Cohen, B., \& Winn, M. I. (2007). Market imperfections, opportunity and sustainable entrepreneurship. Journal of Business Venturing(22), 29 - 49.

Çalışır, M. (2019, 9 20). Faizsiz Bankacılık İlke ve Standartlarına Uyuma İlişkin Tebliğ”ine Yönelik Değerlendirme. İsefam Web Sitesi: https://www.isefam.sakarya.edu.tr/?p=2521 adresinden alındı

Çeker, O. (2017, Mayıs 29). Kitabu'l mudarebe (Muhtar Dersleri 27). Youtube Web Sitesi: https://www.youtube.com/watch?v=Ap25JkcSwV0 adresinden alınd 1 
Çelik, İ. (2017). Meşru Bir Yatırım Aracı Olarak Mudârebe ve Günümüzde Kullanımı. Injosos Al-Farabi International Journal On Social Sciences, 1(3), 381-395.

Döndüren, H. (2012). Delirlleriyle Ticaret ve İktisat İlmihali. İstanbul: Erkam Yayınları.

Durmuş, A. (2011). İslam Hukuku Açısından Günümüz Kredi ve Finansman Yöntemleri. İslam Hukuku Açısından Tarihten Günümüze Kredi ve Finans Yöntemleri (s. 57-109). içinde İstanbul: Ensar Neşriyat.

Ebussuûd, M. İ. (tarih yok). Mecmûatü'l-Fetâvâ. (V. b. Yusuf, Dü.) İstanbul: İstanbul Müftülüğü Kütüphanesi.

Field, A. (2013). Discovering Statistics Using IBM SPSS Statistics, 4th Edition. London: SAGE Publications Ltd.

Gedikli, F. (1996). 16. ve17. asır Osmanlı Şer'iyye Sicillerinde Mudarebe Ortaklığı : Galata Örneği. İstanbul. https://katalog.marmara.edu.tr/eyayin/tez/T0043212.pdf adresinden alındı

Gedikli, F. (2018). Osmanlı Şirket Kültürü - 16. - 17. Yüzyıllarda Mudarebe Uygulaması (2. b.). İstanbul: İz Yayıncilik.

Gönen, D. (2005). İslam Hukukunda Mudarebe (Emek+Sermaye) Şirketinde Tarafların Hak ve Borçları. İstanbul Üniversitesi Hukuk Fakültesi Mecmuası, 63(1-2), 192 - 212.

İnanır, A. (2020). 16. ve 18. Asırlarda Osmanlı Fetva Literatüründe Mudârebe Ortaklığı. Eskiyeni(40), 37-72.

Kallek, C. (2002). Mudârebe. T. D. Vakfi içinde, Türkiye Diyanet Vakfi İslam Ansiklopedisi (s. 359-363). İstanbul: Türkiye Diyanet Vakfı Yayınları.

Merğînânî, A. b. (1990). el-Hidâye şerh-u Bidâyeti'l-mubtedî (Cilt 3). Beyrut: Dâru kütübi'l-ilmiyye.

Nevevî, E. Z. (2006). Ravdatu’t-Talibin (Cilt 3). Beyrut: Darü'l-Kütübi'l-İlmiyye.

Özsoy, Ş. (2012). Sağlam Bankacılık Modeli İle Katılım Bankacılı̆̆ına Giriş. İstanbul: Kuveyt Türk Yayınları.

Riduwan, Rifan, A. A., Adha, M. A., \& Wahyudi, R. (2020). The Problems of Mudarabah Financing Collateral in Islamic Rural Banks. TEST Engineering \& Management(83), 14706 - 14712.

Serahsî, M. b. (2009). el-Mebsût (Cilt 22). Beyrut: Darü'l-Kütübi'l-İlmiyye.

Soufian, M., Forbes, W., \& Hudson, R. (2014). Adapting financial rationality: Is a new paradigm emerging? Critical Perspectives on Accounting, 8(25), 724-742.

Yaran, R. (2011). İslam Hukukuna Göre Hukukî Işlemler ve Hükümleri (Eşya Hukuku ve Borçlar Hukuku). Ankara: Türkiye Diyanet Vakfı Yayınları.

Ziraat Girişim Sermayesi Yatırım Ortaklığı A.Ş. . (2019). 30 Haziran 2019 Ara Dönem Finansal Tablolara İlişkin Sinirl Denetim Raporu. İstanbul: KPMG. 